\title{
How do rigid labor markets absorb immigration? Evidence from France
}

Correspondence: anthony.edo@ cepii.fr

CEPII, 113 rue de Grenelle, 75007

Paris, France

\begin{abstract}
This paper investigates how immigration can affect the labor market outcomes of native workers when their wages are rigid. I use a rich dataset for France and decompose the native workers according to whether they are covered by fixed-term or indefinite-term contracts. Indefinite-term contracts are associated with higher wage protection than fixed-term contracts that allow firms to adjust wages as contracts expire. I use an empirical methodology which captures the direct effects of an immigrant-induced increase in labor supply on the labor market outcomes of natives who have similar skills. I find that the monthly wage of native workers covered by fixed-term contracts decreases in response to immigration, while employment is the margin through which native workers on indefinite-term contracts is affected.
\end{abstract}

JEL codes: F22, J23, J41

Keywords: Immigration, Wage, Employment, Job contract

\section{Introduction}

The impact of immigration on the wages of natives has been analyzed in multiple studies. The main presumption behind these investigations is that wages could adjust to immigration. Standard economic theory indeed suggests that an immigration-induced increase in labor supply should reduce the wages of competing workers and increase the wages of complementary workers. The validity of this prediction however depends on the degree of wage rigidity (Grossman 1982).

By affecting the responsiveness of wages to economic shocks, the institutional context (such as high minimum wages, generous unemployment benefits, strict employment protection, and powerful labor unions) should mitigate any downward wage adjustment following immigration. The role played by labor market institutions in shaping the labor market effects of immigration should be particularly important in continental European countries since they tend to have rigid wages (Nickell 1997; Babecký et al. 2010, 2012; Messina et al. 2010).

In order to quantify the overall impact of immigration on the wages of native workers, a recent wave of European studies thus accounts for the sluggish adjustment of wages (see, e.g., D’Amuri et al. (2010), Felbermayr et al. (2010), and Brücker and Jahn (2011) for Germany; Brücker et al. (2014) for Denmark; and Edo and Toubal (2015) for France). Other studies complement these investigations by examining the 
impact of immigration on the wages and employment of equally skilled native workers. Glitz (2012) for Germany and Edo (2015) for France find that immigration has no detrimental impact on the wages of competing native workers, whereas it reduces their employment. These findings are consistent with Angrist and Kugler (2003) who show for a panel of European countries that the adverse effects of immigration on native employment are magnified in rigid labor markets.

Taken together, these European studies suggest that labor market institutions tend to exert a protective effect on native wages, leaving room for possible employment effects. The present paper goes beyond the existing results by providing direct evidence on the role played by wage rigidities in shaping the impact of immigration on the wages and employment of competing native workers.

An important source of downward wage rigidity in European countries is related to the predominance of indefinite-term contracts (Babecký et al. 2010). By definition, these contracts are characterized by an indefinite term and it is moreover very costly for firms to terminate them. As a result, workers under indefinite-term contracts have more leeway in wage negotiations, which in turn lead to greater wage rigidity. As compared to indefinite-term contracts, fixed-term contracts should provide firms with the ability to adjust their labor cost. Since the duration of fixed-term contracts is relatively short and their termination has no cost, firms can use the turnover of workers on fixed-term contracts to adjust their wage bills by hiring new employees at lower wages. The population of native workers under fixed-term contracts should therefore be subject to lower degree of wage rigidity than those under indefinite-term contracts. By impacting the degree of wage rigidity, the type of job contracts (indefinite or fixed term) may therefore affect the responsiveness of wages and employment to immigration.

This paper investigates that question by providing an empirical investigation on the effects of immigration on the wages and employment of similarly skilled natives according to whether they are covered by indefinite- or fixed-term contracts. Phrased differently, the present paper mainly studies how the wages and employment of different groups of natives are affected by an increase in the number of competing immigrants (at least in the short run). As a result, this paper only deals with partial effects of immigration and does not account for cross-group complementarities, as well as capital and other economic adjustments induced by immigration which should have a positive wage impact on all native workers. ${ }^{1}$ Also, this paper does not consider the positive effects that high-skilled immigration may have on the labor market through human capital externalities (Borjas 2014, chapter 8).

The present paper uses a rich dataset taken from the French labor survey that covers the period from 1990 and 2002. ${ }^{2}$ The French labor market provides an excellent framework for this analysis since it has a rigid wage structure (Card et al. 1999), and around $88 \%$ of workers are covered by indefinite-term contracts. ${ }^{3}$ I use the skill-cell approach by Borjas (2003) and show that immigration has no adverse impact on the wages of competing natives. However, I find that immigration has a negative impact on their employment rates: a $10 \%$ immigrant-induced increase in the number of workers in a particular skill group reduces the employment rate to labor force of natives by 3 to $5 \%{ }^{4}$

Moreover, these results are robust to the implementation of an instrumental variable (IV) strategy. In order to account for the bias that may arise from the endogenous distribution of immigrants across skill groups, I use the historical distribution of 
immigrants across skill groups from the 1982 French census as a predictor for their subsequent flows. ${ }^{5}$ The instrument used in the present paper thus relies on Card (2001) and Peri (2012). It is based on the idea that the stock of previous immigrants has an impact on subsequent flows through network effects, while assuming that past immigrant concentrations are uncorrelated with current unobserved economic shocks.

Then, I implement subsample regressions to decompose the labor market effects of immigration according to whether native workers hold indefinite-term contracts or fixed-term contracts. I find that the average impact of immigration on the labor market outcomes of natives is entirely driven by the population of native workers covered by indefinite-term contracts. The wage insensitivity to immigration of that population is more striking, and the negative employment effect due to immigration remains: firms cannot adjust the wages of native workers under indefinite-term contracts, and therefore, they use their exits (e.g., workers under indefinite-term contracts can quit their jobs, retire, or be laid-off) to replace them by immigrants.

The wage and employment responses of natives under fixed-term contracts to immigration are the opposite. The baseline estimate indicates that a $10 \%$ increase in the size of a skill group due to immigration reduces the monthly wage of natives under fixed-term contracts by around $9 \%{ }^{6}$ As fixed-term contracts have a short duration and terminate at no cost, firms tend to use them as a tool to achieve labor cost flexibility. Moreover, I show that immigration has a negative impact on their fraction of time worked-i.e., the decline in wages experienced by the native workers under fixed-term contracts encourages them to reduce their hours of work. However, I do not find evidence of a negative impact of immigration on the employment rate of competing native workers under fixed-term contracts. This result suggests that native workers under fixed-term contracts only respond to negative wage variations at the intensive margin.

More generally, the asymmetric effects of immigration on the wages and employment of native workers according to their type of job contracts are robust to the implementation of IV estimations. I moreover show that these results are very unlikely to be driven by any selection issue among native workers on who is under each type of contract.

The next section discusses the French institutional framework and proposes some theoretical predictions. Section 3 presents the data, the skill-cell methodology, and provides a discussion on the main identification issues. In Section 4, I show the empirical results. The last section concludes.

\section{The French institutional framework and theoretical predictions}

\subsection{French institutions}

France has a variety of institutional features that should prevent wage adjustment following labor supply shocks (Card et al. 1999). The French labor market is characterized by strict employment protection, a high minimum wage, and generous welfare state benefits. It is also characterized by a high coverage of collective bargaining agreements, with more than $90 \%$ of employees covered by collective bargaining contracts. All these institutional dimensions affect the wage-setting mechanism (Babecký et al. 2010) and the reservation wage of individuals (Cohen et al. 1997), which in turn should have an impact on the responsiveness of wages to labor supply shocks. This is supported by 
Card et al. (1999) who show that labor supply shocks have much less impact on French wage adjustment because of wage rigidities, as compared to the USA and Canada.

For a panel of European countries, Babecký et al. (2010) also find that indefinite-term contracts-characterized by strict employment protection legislation and an indefinite term-have a strong effect on downward wage rigidity. Given that $88 \%$ of the stock of French workers has indefinite-term contracts, this source of rigidity should be important in France.

In France, firms can hire a worker on indefinite-term contracts (contrats à durée indéterminée) or fixed-term contracts (contrats à durée déterminée). While it is difficult and costly to terminate an indefinite-term contract, the termination of a fixed-term contract is not an issue (Kramarz and Michaud 2010). In fact, fixed-term contracts can be renewed twice and their length (including renewal) cannot exceed 18 months. In my data, the median duration of fixed-term contracts is $7 / 8$ months. Firms could therefore use the limited length of fixed-term contracts to adjust their wage bills through labor turnover when hiring new employees or after a renewal. The main goal of fixed-term contracts is precisely to provide firms with the additional flexibility they might need to adjust their production level due to (negative or positive) economic shocks (Bentolila et al. 1994; Goux et al. 2001).

In addition, workers under fixed-term contracts tend to be less protected than those under indefinite-term contracts: the former are less unionized (Amossé and Pignoni 2006) and eligible to lower amounts of unemployment benefits (Ortega and Rioux 2002). ${ }^{7}$ By having less power in the wage-setting process and lower reservation wages, workers under fixed-term contracts should be more likely to experience wage losses in response to economic shocks.

The fact that indefinite-term contracts are more restrictive than fixed-term contracts is consistent with the fact that most hiring (between 70 and $80 \%$ of all entries) by French firms occurs through fixed-term contracts (Abowd and Kramarz 1999, 2003). ${ }^{8}$ Moreover, since the wages of incumbent workers (whatever their job contracts) tend to be inflexible downward, wage adjustment is very likely to be implemented through hiring, as suggested by Babecký et al. (2012) who show that the main strategy used by French firms to adjust their labor cost is through labor turnover.

As a result, the population of workers under fixed-term contracts (high hiring rate and low protection) should be less subject to downward wage rigidities than the population of workers under indefinite-term contracts (low hiring rate and high protection).

\subsection{Theoretical predictions}

Some theoretical predictions about the labor market effects of immigration can be taken based on the French institutional characteristics. With rigid wages and at least some degree of substitutability between natives and immigrants in the production process, an increase in labor supply through immigration should not affect wages. ${ }^{9}$ Instead, immigration should decrease the employment of similarly skilled native workers (at least in the short run), as shown in Grossman (1982) and Angrist and Kugler (2003). For instance, in the case where immigrant wages are less inflexible than native wages, an immigrant-induced shift in labor supply should reduce immigrant wages by more than native wages leading firms to substitute away from natives. Moreover, firms 
may be encouraged to replace natives by immigrants as the latter tend to have lower reservation wages and exert more effort in production than equally productive natives (Galor and Stark 1991; Constant et al. 2011; Malchow-Møller et al. 2012; Edo 2015).

As explained in Section 2.1, one important source of wage rigidities in France lies in the type of job contracts. Being less protected and more subject to labor turnover, the population of native workers under fixed-term contracts should have a wage structure that is less rigid than those under indefinite-term contracts. Thus, an immigrantinduced increase in labor supply should reduce the wage of competing native workers under fixed-term contracts. The employment reaction of the native population under fixed-term contracts should then depend on their labor supply elasticity.

In contrast, the wage of native workers under indefinite-term contracts should be protected from downward wage pressure (at least in the short run). By leaving their wages unaffected, immigration should however reduce its employment level. Each year, workers under indefinite-term contracts quit their jobs, they retire, or they are laid-off (Abowd and Kramarz 1999). While most hiring is on fixed-term contracts, the numbers of separations on indefinite- and fixed-term contracts are mostly similar (half of all separations is due to the end of fixed-term contracts, the other half is due to quits, retirement, lay-off). As a result, employers could use the exits of natives under indefiniteterm contracts to replace them by immigrants.

\section{Data description, methodology, and identification issues}

\subsection{Data and selected sample}

The empirical study is based on the French annual labor force survey (LFS) covering the period 1990 through 2002. This wave of annual data has been collected by the French National Institute for Statistics and Economic Studies (INSEE) in a very consistent way over the period. It provides detailed information on demographic, social, and economic characteristics of around 145,000 individuals per year. In order to make our sample representative of the French population, we systematically use an individual weight (computed by the INSEE). This weight indicates the number of individuals each observation represents in the total population.

Our empirical analysis uses information on individuals aged from 16 to 64. I follow several studies on immigration and drop all individuals who are self-employed (such as farmers, business owners, liberal professions), in military occupations or enrolled at school (Borjas, 2003; Ottaviano and Peri 2012). I also exclude all individuals who work in the clergy since the wage-setting mechanism in that occupation should differ from the wage-setting of all other workers.

I define an immigrant as an individual who is born outside France and who is either a noncitizen or a naturalized citizen. All other individuals are considered as natives. This definition is similar to Borjas (2003) as well as to Ottaviano and Peri (2012).

Each native worker having a contrats à durée indéterminée (CDI) or a permanent contract from the public sector is considered as covered by an indefinite-term contract. All other native workers are considered to have a fixed-term contract.

This paper uses the education-experience dimension to identify the labor market impact of immigration (Borjas 2003). Our data provide six education levels: college graduate, some college, high school graduate, some high school, just before high school, and 
no education. I will use them to build education groups. The LFS has also the advantage to give the age of ending school. I thus compute work experience by subtracting for each individual the age of ending school from reported age (Mincer 1974). This measure does not account for periods of inactivity and unemployment. This issue is particularly important explaining why my study only focuses on male individuals. Finally, the analysis is restricted to individuals who have between 1 and 40 years of experience.

In this paper, I study how immigration affects the wages, hours worked, and employment of native workers. First, I use monthly earnings to capture native wages. The survey reports for each worker the monthly wage net of employee payroll tax contributions adjusted for nonresponse (the variable is called "salred"). I deflate the wage data using the French Consumer Price Index provided by the INSEE and compute the mean log monthly wage at the skill-cell level, as suggested in Katz and Murphy (1992) and Borjas $(2003,2012) .{ }^{10}$ As in Edo (2015), I use the sample of native workers in full-time employment (representing $96.3 \%$ of all native workers) to have a homogenous population of workers.

Second, I compute the log of hours worked per week by natives for each skill cell. For the native workers who do not have regular and fixed hours worked, I use their number of hours worked during the previous week.

Third, I use employment rates to capture the employment opportunities of natives-this strategy follows the studies by Altonji and Card (1991), Card (2001), Angrist and Kugler (2003), and Glitz (2012). For each skill group, I compute the log employment rate to labor force and the log employment rate to population. Note that the two employment rates can be combined to infer the participation rate of natives. At the numerator of the two employment rates, I use the number of native workers in full-time employment. This choice is consistent with the sample used to compute average wages per skill cell.

Table 1 provides some summary statistics on real monthly wages, hours worked per week, and employment rates of male natives by year (1990 and 2002) and across education groups (high education, medium education, and low education). The first panel of the table provides the average monthly wage of full-time male native workers, as well as the wage distribution at different percentiles. One can see that monthly wages increase with the level of education. Moreover, the dispersion of wages across workers

Table 1 Descriptive statistics on wages and employment for male natives

\begin{tabular}{|c|c|c|c|c|c|c|}
\hline & \multicolumn{3}{|l|}{1990} & \multicolumn{3}{|l|}{2002} \\
\hline & High & Medium & Low & High & Medium & Low \\
\hline Average monthly wages & 2120.8 & 1287.1 & 1122.2 & 2068.5 & 1274.6 & 1161.8 \\
\hline 90th percentile & 3442.8 & 1969.3 & 1627.6 & 3520.7 & 2233.4 & 1668.8 \\
\hline 75th percentile & 2570.0 & 1448.3 & 1245.0 & 2424.7 & 1441.6 & 1302.8 \\
\hline 50th percentile & 1816.7 & 1108.2 & 990.9 & 1728.2 & 1116.7 & 1048.5 \\
\hline 25th percentile & 1354.3 & 889.3 & 816.1 & 1276.9 & 930.0 & 868.5 \\
\hline 10th percentile & 1073.5 & 747.0 & 686.0 & 992.6 & 793.0 & 743.2 \\
\hline Hours worked per week & $41.7(10.8)$ & $41.3(7.2)$ & $41.1(6.7)$ & $41.3(10.1)$ & $38.8(7.5)$ & $38.2(6.8)$ \\
\hline Employment rate to labor force & $95.1 \%$ & $92.1 \%$ & $86.0 \%$ & $91.1 \%$ & $90.5 \%$ & $82.3 \%$ \\
\hline Employment rate to population & $91.3 \%$ & $88.5 \%$ & $78.9 \%$ & $96.5 \%$ & $85.4 \%$ & $72.0 \%$ \\
\hline
\end{tabular}


within education groups is relatively strong. On average, the number of hours worked per week has declined over the period of interest (standard deviations are given in parentheses) - this trend is consistent with the reduction in the length of the standard workweek from 39 to $35 \mathrm{~h}$ in 2000 in France. The last panel of Table 1 presents the employment rates of full-time male native workers as a percentage of the active male native population (employment rate to labor force) and as a percentage of the total male native population (employment rate to population). By construction, the employment rate to labor force is always higher, and more generally, both employment rates increase with schooling.

\subsection{The skill-cell methodology}

This paper investigates the labor market effects of immigration by decomposing the national labor market into skill groups defined in terms of education and experience. I study the labor market effects of immigration at the national level, rather than at the regional (or locality) level because "natives may adjust to the immediate impact of immigration in an area by moving their labor or capital to other localities" (Borjas 1997, p. 15). Moreover, I define skill groups in terms of education and experience, rather than in terms of occupation because "individuals can move between occupations, and they would be expected to do so if there is a relative oversupply of workers in a particular occupation" (Card 2001, p. 32). Yet, the response of natives to immigration should diffuse the impact of immigration into geographic regions and occupations that were not directly affected by the immigrant influx, leading to biased results (Borjas 2006).

In this paper, I classify individuals into three education groups and eight experience groups. The three education levels correspond to tertiary education (some college or more), secondary education (high school graduates and some high school), and primary education (less than high school). This choice strictly follows Edo and Toubal (2015) who show for France (over the period 1990-2010) that three education groups are an accurate decomposition to investigate the labor market impact of immigration. The use of three education groups is also consistent with multiple European studies on the labor market impact of migration (D’Amuri et al. 2010; Gerfin and Kaiser 2010; Elsner 2013), as well as with Brücker et al. (2014, p. 211) who indicate that "it is most suitable to distinguish three education groups in European labor markets." Finally, I follow most the literature and divide each education group into eight experience groups: $1-5$ years, 6-10 years, 11-15 years, ..., 36-40 years of work experience.

The empirical analysis is based on estimates from the following equation:

$$
y_{j k t}=\alpha+\beta \cdot p_{j k t}+\theta_{j}+\theta_{k}+\theta_{t}+\theta_{j} \times \theta_{k}+\theta_{j} \times \theta_{t}+\theta_{k} \times \theta_{t}+\varepsilon_{j k t},
$$

where the dependent variable is a measure of native wage, hours worked, or employment at time $t$ with education $j$ and experience $k$. Following Borjas (2003), the immigrant supply shock experienced in a particular skill cell is captured by the $p_{j k t}$ variable. This variable is the ratio of immigrants with education $j$ and experience $k$ to total labor force.

$$
p_{j k t}=M_{j k t} /\left(M_{j k t}+N_{j k t}\right),
$$

where $N_{j k t}$ and $M_{j k t}$ are the number of natives and immigrants in the male labor force located in the education-experience-time cell $(j, k, t)$, respectively. This measure is used 
in various studies-see, e.g., Aydemir and Borjas (2007), Borjas et al. (2010), Cortes (2008), and Bratsberg et al. (2014). In France, the share of male immigrants in the workforce increased from $7 \%$ in 1990 to $8.5 \%$ in 2002. The size of this supply shock was not evenly distributed across education-experience groups. Over our period of interest (19902002), immigration has disproportionately increased the number of highly and mediumeducated workers (Edo and Toubal 2015). Moreover, these supply shifts did not affect all age groups within these populations equally. The immigrant supply shock experienced in the highly and medium-educated groups was mainly concentrated in cells with more than 10 years of experience and below 35 years of experience (Edo 2015).

Equation (1) includes education fixed effects $\theta_{j}$, experience fixed effects $\theta_{k}$, and year fixed effects $\theta_{t}$. They control for differences in labor market outcomes across education groups, experience groups, and over time. In addition, I interact these terms to allow for the impact of skills (i.e., education and experience) on wages and employment to vary over time and the impact of education to vary with the experience level. This identifying strategy implies that $\beta$ is identified from changes within skill cells over time. I will also cluster the standard errors by skill cells to adjust for the possible serial correlation that may exist within cells.

\subsection{Endogeneity of the immigrant share}

One important identification issue is related to the endogenous distribution of immigrants across skill cells. Immigrants are attracted mostly to skill cells that offer the best current labor market opportunities, which typically bias upward the estimates of the labor market effects of immigration (Borjas 2003; Glitz 2012; Ottaviano and Peri 2012; Brücker et al. 2014). To address this issue, I follow the existing literature in using an instrumental variable approach. More specifically, I use an instrument based on historic settlement patterns among immigrants - this instrument is inspired from Altonji and Card (1991), Card (2001), Peri (2012), and D'Amuri and Peri (2014). Indeed, the settlement decision of new immigrants are partly determined by the presence of earlier immigrants, mainly through network externalities (Gross and Schmitt 2003; Epstein and Gang 2010)_past immigrants may, for instance, provide new immigrants with information on labor and housing markets. The network effect should be particularly strong between immigrants with the same cultural, linguistic, and educational background (Dustmann et al. 2005).

I exploit this "network justification" and use the past educational composition of immigrants from a given national origin and experience group. Then, I allocate the immigrant population present in France at time $t$ with experience $k$ to the various education groups based on the past educational distribution of immigrants from country $c$. I use the French census of 1982 to infer the initial distribution of immigrants across education groups for each origin-experience group. ${ }^{11}$ I then compute the imputed number of immigrants $\hat{M}_{j k t}$ for each education-experience-time cell by multiplying in each year the 1982 educational distribution of immigrants of each experience-origin group by the total number of immigrants from the same country and experience group as follows: ${ }^{12}$

$$
M_{j k t}=\sum_{c}\left(M_{j k}^{c}(1982) / M_{k}^{c}(1982)\right) \times M_{k}^{c}(t) .
$$

Based on the imputed number of immigrants, I can finally compute the predicted share of immigrants $P_{j k t}$ and use it as instrument for $P_{j k t}$. This instrument should predict different levels of immigration in a given education-experience cell at different points in time 
for reasons unrelated to better labor market opportunities. The assumption that the educational distribution of type-c immigrants within experience groups is uncorrelated with current economic shocks might be restrictive. Indeed, serial correlation in wages and employment at the skill-cell level would tend to challenge the exclusion restriction of our instrument. Moreover, as indicated in Dustmann et al. (2005, p. 328), "the assumption that lagged values of immigrant stocks are correlated with outcome changes only through their relation with immigrant inflows is an identifying assumption that is not testable." Thus, a way to minimize the potential correlation between past immigration and current economic shocks is to use a sufficient time lag to predict the actual number of immigrants (Dustmann et al. 2005). In this regard, I will exclude the years 1990 and 1991 when running IV regressions. This procedure allows me to compute $\hat{M}_{j k t}$ based on immigration patterns that took place 10 years ago and is more likely to guarantee the exclusion restriction of the instrument. In addition, another way to check the robustness of our instrumentation technique will be to verify that $\hat{\beta}^{O L S}<\hat{\beta}^{I V}$ inasmuch as the ordinary least squares (OLS) estimates of $\beta$ tend to be upward biased.

An additional source of bias may come from sampling errors in the measure of $P_{j k t}$ due to small sample sizes (Aydemir and Borjas 2011). Any measurement error in the computation of immigrant shares should lead to an attenuation bias in the estimated wage and employment effects of immigration. The attenuation bias introduced by sampling error should be aggravated when considering small labor markets. The decomposition of the French labor market into skill groups (rather than skill-region groups), which are moreover not too narrowly defined (e.g., the present study uses three education groups, instead of four in Borjas (2003) and Ottaviano and Peri (2012) or five in Borjas (2014)), should limit any sampling error in the measure of immigrant shares. In any event, our IV strategy should correct for the attenuation bias in estimating the wage and employment effects of immigration (given that the instrument should be uncorrelated with measurement error).

The measurement error in the computation of immigrant shares might be strengthened if immigrants are more likely to accept jobs requiring lower education than they have, as shown by Dustmann et al. (2013) for the UK. If immigrants downgrade their skills, their assignment to skill cells should be inaccurate leading to overestimate the immigrant contribution to the supply of highly educated workers and underestimate the immigrant contribution to the supply of low-educated workers. The measurement error introduced by the misclassification of workers across skill groups should cause an additional attenuation bias in the estimates of the wage and employment effects of immigration. In France, however, the existing evidence suggests that immigrants do not tend to downgrade their skills. In particular, Docquier et al. (2014) find that highly educated immigrants are as likely to be in highly skilled occupation as natives. Hence, accounting for the potential downgrading of immigrants in France does not alter their simulations quantifying the wage effects of immigration over the 1990-2000 period. This set of results is consistent with a report by the OECD (2007) showing that France is one of the OECD countries with the lowest rate of downgrading among immigrants (see Tables II.2 and II.A3.1 of the report). In any case, the attenuation bias that may arise due to immigrants' educational downgrading should be attenuated by our instrumentation strategy (since our instrument should not be correlated with the error term). 


\subsection{Selection of native workers into the type of their job contract}

As seen in Section 2.1, the type of job contract may be an important determinant of (downward) wage rigidity. I therefore use the heterogeneity of native workers in terms of their job contract to investigate the importance of job contract in shaping the labor market effects of immigration. One limitation of this exercise may be related to a selection problem among native workers in the type of their job contracts: native workers under fixed- and indefinite-term contracts may differ systematically within and across skill cells along various socio-economic dimensions. For instance, fixed-term contract workers might be less productive, less educated, and younger than workers under indefinite-term contracts, implying different wage and employment effects in response to immigration. As a result, the prevalence of differences in the estimated effects of immigration on the wages and employment of natives by job contract may be unrelated to their job contract but rather to differences in other characteristics correlated with their contract.

On the one hand, native workers under fixed- and indefinite-term contracts may compete for different types of jobs, and they might not be equally productive within education-experience groups. I examine this precise issue by estimating the elasticity of substitution between workers under fixed- and indefinite-term contracts using a traditional nested constant elasticity of substitution (CES) framework (Borjas 2003; Manacorda et al. 2012; Ottaviano and Peri 2012). By equating the wage to the marginal product of labor for the native workers under fixed-term contracts (FTC) and indefinite-term contracts (ITC), one can derive the relative demand function:

$$
\log \left(w_{j k t}^{\mathrm{FTC}} / w_{j k t}^{\mathrm{ITC}}\right)=\log \left(\phi_{j k t}^{\mathrm{FTC}} / \phi_{j k t}^{\mathrm{ITC}}\right)-\frac{1}{\sigma_{N}} \log \left(N_{j k t}^{\mathrm{FTC}} / N_{j k t}^{\mathrm{ITC}}\right),
$$

where $\sigma_{N}$ is the elasticity of substitution between native workers under FTC and ITC and $w_{j k t}^{\mathrm{FTC}}$ and $w_{j k t}^{\mathrm{ITC}}$ are respectively the wages of natives under FTC and ITC in a particular education-experience group $(j, k)$ at time $t$. In order to compute relative wages, I will follow the standard approach and use the mean of log wages (Katz and Murphy 1992; Borjas et al. 2012). The relative labor supply is measured by the log relative number of native workers under FTC in employment. The term $\log \left(\phi_{j k t}^{\mathrm{FTC}} / \phi_{j k t}^{\mathrm{ITC}}\right)$ captures the relative productivity of native workers under FTC. In order to estimate $-1 / \sigma_{N}$, I will assume that the relative productivity term can be captured by a vector of fixed effects and a group-specific error term uncorrelated with the log relative supply of natives under FTC.

It is important to notice that Eq. (4) is derived under the assumption that all workers are paid their marginal productivity. However, this assumption may not be necessarily verified in France as the French institutional framework should generate downward wage rigidities, especially for the workers under ITC (as discussed in Section 2.1). Within an asymmetric context where the wages of workers under FTC are more flexible than those of workers under ITC, the estimates of $-1 / \sigma_{N}$ should be then interpreted as lower bounds of the true value of $-1 / \sigma_{N}$ (i.e., a negative and significant estimate of $-1 / \sigma_{N}$ should definitely suggest that workers under ITC and FTC are imperfect substitutes). It may also be that all French wages are inflexible regardless of workers' job contract, so that labor markets are not clear. In that case, it is possible to 
derive from the same CES production function an alternative equation where relative labor supply is now the dependent variable and relative wages are the explanatory variable-i.e., employment is now endogenously determined once wages are fixed. ${ }^{13}$

In order to investigate the degree of substitution between workers in FTC and ITC, panel A of Table 2 follows the standard approach and reports the estimated values of $1 / \sigma_{N}$ from Eq. (4), whereas panel B reports the estimated values of $-\sigma_{N}$ by using the alternative equation where the dependent variable is the relative employment of FTC (as in Brücker et al. (2014) - see footnote 13). Student's T-statistics are given in parentheses below the estimated coefficients. I use 312 skill groups (defined in terms of education, experience, and time) to run regressions and focus on the sample of full-time native workers. I capture the relative productivity term by using various combinations of education-experience-time fixed effects.

In panel A, I use the relative log monthly wages as the baseline-dependent variable, as well as relative hourly wage as an alternative. In panel B, the regressors of interest are the relative monthly wage of FTC workers (specification B1) and the relative hourly wage of FTC workers (specification B2). As in Ottaviano and Peri (2012), each regression uses the total number of observations used to calculate average wages as analytical weights. Standard errors are heteroscedasticity-robust and clustered around educationexperience groups.

For all panels and specifications, the estimated coefficients are never significant pointing to a high degree of substitution between natives under FTC and natives under ITC-native workers under fixed-and indefinite-term contracts tend to be perfect substitutes in production. As a result, within a particular skill cell, these two groups of workers do not differ in terms of their productive characteristics. Our results therefore suggest that the (potential) selection issue into the type of job contract that may arise due to within-cell differences between workers under FTC and ITC should be limited.

On the other hand, the selection problem into the type of job contract may arise due to cross-cell differences-native workers under ITC could be much more educated and older than those in FTC implying different reactions of their labor market outcomes in response to immigration. In this regard, Table 4 (in the Appendix) shows very similar educational distributions between native workers under FTC and ITC. However, Table 5 (in the Appendix) shows that FTC native workers tend to have lower work experience than ITC native workers. The higher sensitivity of native wages under FTC may thus be due to the fact that they tend to be disproportionately young. Table 5 (in the Appendix) also shows that the number of

Table 2 Substitution elasticity between ITC and FTC workers

\begin{tabular}{lllll}
\hline & 1 & 2 & 3 & 4 \\
& A. Relative wage as the dependent variable & \\
\hline A1. Monthly wage & $0.01(0.74)$ & $0.01(0.46)$ & $0.01(0.34)$ & $0.03(0.63)$ \\
A2. Hourly wage & $0.01(1.04)$ & $0.01(0.58)$ & $0.01(0.24)$ & $0.01(0.30)$ \\
& B. Relative employment as the dependent variable \\
B1. Relative monthly wage as the explanatory variable & $0.96(0.67)$ & $0.10(0.45)$ & $0.06(0.34)$ & $0.12(0.60)$ \\
B2. Relative hourly wage as the explanatory variable & $1.09(0.91)$ & $0.11(0.55)$ & $0.03(0.24)$ & $0.05(0.29)$ \\
Time fixed effects (FE) & No & No & Yes & Yes \\
Education-experience FE & No & Yes & Yes & Yes \\
Education-time FE & No & No & No & Yes \\
Experience-time FE & No & No & No & Yes \\
\hline
\end{tabular}


native workers having between 35 and 40 years of work experience is very low. Their measured employment rates and monthly wage may therefore be imprecise, introducing some noise in estimating the labor market effects of immigration. In order to show that my estimates are not driven by the experience groups below 10 years and after 35 years, I will exclude them in a robustness test. This test is thus a way to show that my interpretation of the results is unlikely to be driven by a selection issue into the type of job contracts hold by native workers.

\section{Empirical results}

\subsection{Preliminary analysis}

Figure 1 provides a preliminary look at the correlation between the (log) monthly wage of natives for each skill group and the share of immigrants for that group. As in Borjas (2003), the log wage and the immigrant share are differenced from their respective skill group's mean after removing year effects from the differenced data. Thus, a positive (negative) number reflects a higher (lower) level in wages or in the immigrant share relative to their respective mean. Presumably, the skill cells which experience the largest supply shocks (positive number) would be the ones where monthly wages increase the least (negative number).

However, the figure suggests no correlation between monthly wages and the immigrant share across skill groups. This fact differs considerably with the strong and negative basic correlation found in the US case (Borjas 2003) but is consistent with a wage structure that is relatively less flexible in France (Card et al. 1999).

Figure 2 presents the scatter diagram relating the deviation in the $(\log )$ employment to labor force rate and the deviation in the immigrant share to their respective skill group's mean after removing any year-specific effects that are common to all groups for a given year. The figure indicates a negative and significant relationship: the estimated coefficient (and $T$-statistic) is $-0.28(-2.37)$. This preliminary result suggests that the employment rate has grown fastest for the native workers in those skill groups that have experienced the lowest immigration supply shocks.

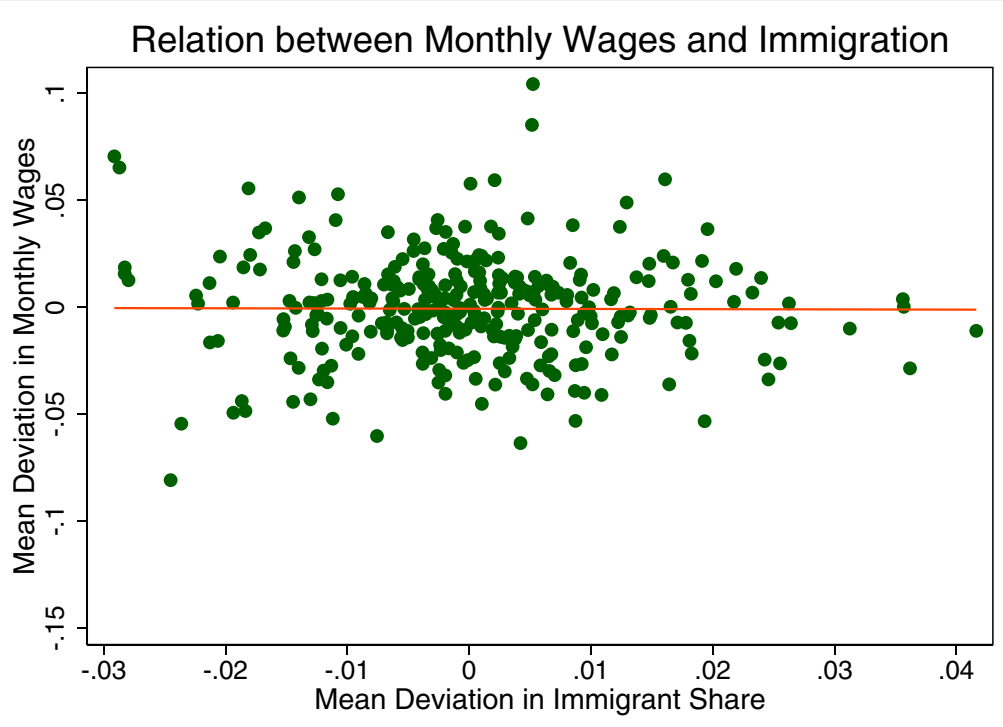

Fig. 1 Relation between monthly wages and immigration 
The basic correlations provided by Figs. 1 and 2 are consistent with other theoretical and empirical findings (Grossman 1982; Angrist and Kugler 2003; D’Amuri et al. 2010; Glitz 2012): when wages are inflexible downward, the level of (un)employment tends to adjust in response to immigration. The remainder of this paper tests the robustness of these correlations and studies the role played by wage rigidities on the wage and employment responses to immigration by disaggregating the sample of native workers by job contract.

\subsection{Econometric results}

This section reports and discusses the OLS- and IV-estimated effects of immigration on the wages and employment of native workers within the same skill group. Before presenting the main results, I briefly describe the first-stage estimates from the IV regressions.

\subsubsection{First-stage estimates}

In the first-stage of the IV regressions, I regress the variable of interest (i.e., the share of immigrants in the workforce) on the instrument (i.e., the predicted share of immigrants as discussed in Section 3.3) and a complete set of educationexperience fixed effects $\delta_{j k}$, education-time fixed effects $\delta_{j t}$, and experience-time fixed effects $\delta_{k t}$ as follows:

$$
p_{j k t}=\alpha^{\prime}+\beta^{\prime} \cdot \hat{p}_{j k t}+\delta_{j k}+\delta_{j t}+\delta_{k t}+u_{j k t},
$$

with $u_{j k t}$ being the error term. All first-stage estimates indicate a strong positive correlation between the instrument and the immigrant share. ${ }^{14}$ The estimated coefficients on the instrument are around 0.70 and always significant at $1 \%$ level. Moreover, the $F$ test of exclusion is always above 20. This is larger than the lower bound of 10 suggested by the literature on weak instruments indicating that our IV estimates do not suffer from a weak instrument problem (Stock et al. 2002). As a result, the first-stage statistical tests suggest that $\hat{p}_{j k t}$ is a reasonably strong instrument.

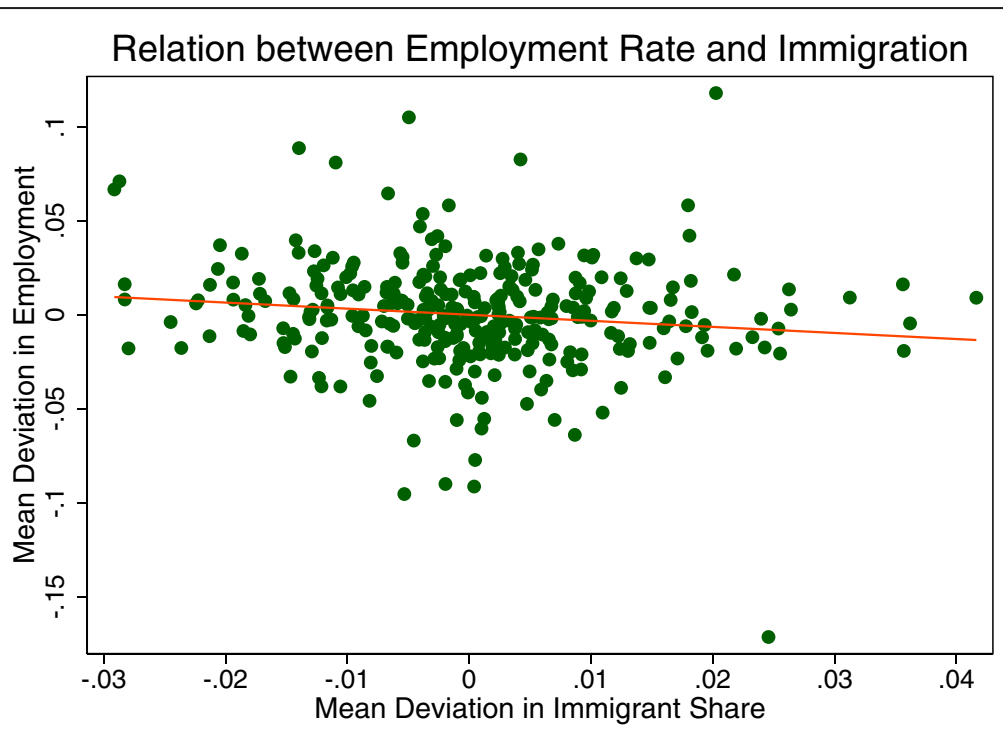

Fig. 2 Relation between employment rate and immigration 
Table 3 The immigration impact on native wages and employment

\begin{tabular}{|c|c|c|c|c|c|c|c|c|}
\hline & \multicolumn{2}{|l|}{$\begin{array}{l}\text { Monthly wage } \\
\text { (1) }\end{array}$} & \multicolumn{2}{|l|}{$\begin{array}{l}\text { Hours worked } \\
\text { (2) }\end{array}$} & \multicolumn{2}{|l|}{$\begin{array}{l}\text { Empl. rate to LF } \\
\text { (3) }\end{array}$} & \multicolumn{2}{|c|}{$\begin{array}{l}\text { Empl. rate to pop } \\
\text { (4) }\end{array}$} \\
\hline & OLS & IV & OLS & IV & OLS & IV & OLS & IV \\
\hline & A. All workers & & & & & & & \\
\hline \multirow[t]{2}{*}{ A1. Basic regression } & $0.09(0.55)$ & $-0.02(-0.06)$ & $-0.02(-0.26)$ & $0.03(0.27)$ & $-0.37^{* * *}(-2.88)$ & $-0.62^{* * *}(-2.69)$ & $-0.33^{* *}(-2.41)$ & $-0.85^{* * *}(-2.63)$ \\
\hline & \multicolumn{4}{|c|}{ B. Workers with indefinite-term contracts } & & & & \\
\hline B1. Basic regression & $0.19(1.18)$ & $0.17(0.63)$ & $-0.02(-0.33)$ & $0.09(0.83)$ & $-0.68^{* *}(-2.60)$ & $-1.10^{* *}(-2.43)$ & $-0.63^{* *}(-2.39)$ & $-1.30^{* *}(-2.44)$ \\
\hline $\begin{array}{l}\text { B2. Log of natives as } \\
\text { additional regressor }\end{array}$ & $0.15(1.06)$ & $-0.11(-0.48)$ & $-0.04(-0.56)$ & $-0.03(-0.37)$ & $-0.64^{* *}(-2.48)$ & $-0.82^{*}(-1.82)$ & $-0.59 * *(-2.23)$ & $-0.95^{* *}(-2.03)$ \\
\hline $\begin{array}{l}\text { B3. Exp. between } 10 \\
\text { and } 35 \text { years }\end{array}$ & $0.21(0.84)$ & $0.01(0.08)$ & $-0.20^{*}(-2.19)$ & $-0.02(-0.13)$ & $-0.15(-0.31)$ & $-0.81^{* *}(-2.08)$ & $-0.21(-0.42)$ & $-0.80^{* *}(-2.14)$ \\
\hline \multirow{2}{*}{$\begin{array}{l}\text { B4. } \log \left(M_{j k t} / N_{j k t}\right) \\
\text { instead of } p_{\mathrm{jkt}}\end{array}$} & $0.01(0.65)$ & $0.02(0.63)$ & $-0.00(-0.34)$ & $0.01(0.85)$ & $-0.06^{* * *}(-3.14)$ & $-0.12^{* *}(-2.45)$ & $-0.06^{* *}(-2.62)$ & $-0.14^{* *}(-2.41)$ \\
\hline & \multicolumn{4}{|c|}{ C. Workers with fixed-term contracts } & & & & \\
\hline C1. Basic regression & $-0.75^{*}(-2.05)$ & $-0.94^{*}(-1.83)$ & $-0.04(-0.24)$ & $-0.43^{* *}(-2.02)$ & $0.42(0.48)$ & $1.61(1.44)$ & $0.39(0.44)$ & 1.28 (1.12) \\
\hline $\begin{array}{l}\text { C2. Log of natives } \\
\text { as additional regressor }\end{array}$ & $-0.97^{* *}(-2.23)$ & $-1.21^{* *}(-2.30)$ & $-0.09(-0.41)$ & $-0.51^{* *}(-2.03)$ & $0.51(0.57)$ & $1.90(1.63)$ & $0.53(0.60)$ & 1.69 (1.39) \\
\hline $\begin{array}{l}\text { C3. Exp. between } 10 \\
\text { and } 35 \text { years }\end{array}$ & $-1.97^{* * *}(-3.48)$ & $-1.76^{* *}(-2.51)$ & $-0.82^{* *}(-2.78)$ & $-1.15^{* *}(-2.10)$ & $-1.72(-1.34)$ & $2.42(1.14)$ & $-1.77(-1.38)$ & $2.43(1.14)$ \\
\hline $\begin{array}{l}\text { C4. } \log \left(M_{j k t} / N_{j k t}\right) \\
\text { instead of } p_{j k t}\end{array}$ & $-0.05^{*}(-1.82)$ & $-0.10^{*}(-1.79)$ & $0.00(0.06)$ & $-0.05^{*}(-1.89)$ & $-0.03(-0.44)$ & $0.17(1.43)$ & $-0.03(-0.46)$ & $0.14(1.12)$ \\
\hline
\end{tabular}

Note: This table reports the estimated effect of the immigrant share on the monthly wage, hours worked, and employment rates of male natives. Standard errors are adjusted for clustering within education-experience cells.

$T$-statistics are in parentheses

$*{ }^{* *}$, and ${ }^{* *}$ indicate significance at 10,5 , and $1 \%$, respectively 


\subsubsection{Wage and employment effects of immigration}

Table 3 reports the estimated effect of the immigrant share on the monthly wage, hours worked, and employment of competing native workers. For each specification and dependent variable, I report the OLS- and IV-estimated coefficients on the immigrant share. All the regressions are based on annual variations, and the baseline sample has 312 observations (i.e., 13 years of data, 3 education groups, and 8 experience groups). As in Borjas (2003), regressions are weighted by the number of native workers used to calculate the dependent variable.

In Table 3, the first specification (A1) reports the estimates of $\beta$ for the overall population of native workers. The OLS- and IV-estimated coefficients indicate that immigration has no detrimental impact on the monthly wage of competing native workers. Using the same empirical model, Borjas (2003) and Aydemir and Borjas (2007) find a wage reduction by 3-4\% for the USA and Canada. This contrast between our studies points to the dampening effect of wage rigidities in France. Moreover, I find that the immigrant share does not affect the number of hours worked per week by native workers. As their wages are unaffected by immigration, native workers do not have any incentive to modify their fraction of time worked.

Columns (3) and (4) show an inverse and significant relationship between immigrantinduced supply shifts and the employment rates of competing natives. The OLS estimate presented in column (3) implies that a $10 \%$ immigration-induced increase in workers within a skill cell reduces the employment rate to labor force of natives in that cell by $3.1 \% .{ }^{15,16}$ Instrumenting for the immigrant share produces uniformly more negative effects (falling from -0.37 to -0.62 in column (3) and from -0.33 to -0.85 in column (4)). This is consistent with the fact that the negative OLS estimates of $\beta$ have to be interpreted as a lower bound of the true immigration impact.

This first set of results is consistent with economic theory: when wages are inflexible downward, the level of unemployment in the economy increases following immigration. The fact that countries with rigid wages tend to experience employment losses due to immigration is moreover supported by Glitz (2012) for Germany and Angrist and Kugler (2003) for a panel of 18 European countries.

In the remaining panels of the table, I decompose the population of native workers by job contract. Specifications B1 to B4 focus on the population of native workers under indefinite-term contracts, while specifications $\mathrm{C} 1$ to $\mathrm{C} 4$ study the population of native workers under fixed-term contracts. ${ }^{17}$ For panels $\mathrm{B}$ and $\mathrm{C}$, I first implement a basic regression that is similar to specification A1. As explained in Borjas (2003) and Bratsberg et al. (2014), the evolution of the immigrant share over time may be driven by changes in the native labor supply (as the number of natives in the workforce is at the denominator of the immigrant share). Specifications B2 and C2 thus control for this possibility and include the log of the number of natives in the workforce as additional regressor. In specifications B3 and C3, I restrict the analysis to experience groups between 10 and 35 years to show, in particular, that our results are not driven by the fact that native workers under fixed-term contracts tend to be disproportionately young. The last specification of panels B and $\mathrm{C}$ test the robustness of the results to an alternative definition of immigrant penetration within a skill group. Instead of using the share of immigrants in the labor force, specifications $\mathrm{B} 4$ and $\mathrm{C} 4$ use the log ratio between the number of immigrants and the number of natives in the workforce. As a result, the estimated coefficients in specifications B4 and C4 have to be interpreted as elasticities. 
The estimations provided in panel B are consistent with those provided in panel A. First, the share of immigrants has no impact on native wages. This indicates that the population of native workers under indefinite-term contracts is protected from wage losses. Second, the IV-estimated coefficients displayed in column (2) show that immigration does affect the fraction of time worked by the natives who remain in their jobs. Third, the inverse and significant relationship between immigration and employment remains: an immigrant-induced increase in the size of the workforce in a skill group decreases the employment rate of natives in that group. A $10 \%$ rise in the immigrant labor supply in a skill group decreases the native employment rate to labor force in that group by $9.2 \%$ (according to specification B1) and $12.0 \%$ (according to specification B4). As explained in Section 2.2, firms may replace the natives under indefinite-term contracts who leave their jobs by immigrants. This substitution mechanism could be profitable for firms, especially because immigrants tend to accept lower wages and exert more effort in production than equally skilled natives (Malchow-Møller et al. 2012; Edo 2015).

The estimated effects of immigration in panel C contrast with those presented in panel B. In panel $\mathrm{C}$, I find that immigration is negatively associated to native wages and uncorrelated with their employment rates. More specifically, the estimates indicate that immigration lowers the monthly wage of the population of native workers under fixed-term contracts. This wage adjustment is possible through the high turnover of these workers which is moreover less protected. From the IV estimation presented in specification $\mathrm{C} 1$, the wage elasticity implies that a $10 \%$ immigrant-induced increase in the number of workers in a particular skill group reduces the monthly wage of that group by around $7.9 \%{ }^{18}$ This result is consistent with standard economic model: when wages are not downwardly rigid, immigration lowers the wage of competing workers. This wage elasticity is moreover close to that of Llull (2014) who finds a wage elasticity of -1.2 for the USA after instrumentation.

When focusing on skill groups between 10 and 35 years of experience (specification $\mathrm{C} 3$ ), the wage elasticity becomes stronger than in the basic regression (specification $\mathrm{C} 1$ ). One explanation lies in the fact that the immigrant supply shock has been mainly concentrated within these specific experience groups (Edo 2015). Thus, the relationship between immigration and the wages of natives under fixed-term contracts may be better captured in specification C3.

The negative wage reaction of native workers under fixed-term contracts due to immigration is consistent with the IV estimates presented in column (2): immigration has a negative impact on the fraction of time worked by native workers under fixed-term contracts. As immigration decreases monthly wages, native workers tend to respond at the intensive margin by reducing their hours of work. However, I find that immigration does not reduce the employment of competing natives under fixed-term contracts (the estimated coefficients in columns (3) and (4) are insignificant and have moreover an unexpected sign). This result suggests that the labor supply of natives under fixed-term contracts is not responsive to wages at the extensive margin-i.e., native workers under fixed-term contracts prefer to reduce their number of hours worked rather than to leave their jobs after wage reductions.

\section{Conclusions}

This paper investigates the impact of immigration on the wages and employment of similarly skilled native workers in France, a country which is characterized by a rigid wage structure. I decompose the population of native workers by job contract to 
investigate how job contract (and therefore wage rigidity) can protect the labor market outcomes of natives from immigration.

I find that immigration has no wage impact on the population of native workers under indefinite-term contracts, whereas it reduces the wages of the native population under fixed-term contracts. This asymmetric wage impact indicates that the wages of workers under fixed-term contracts can be manipulated by firms to adjust labor cost. Since fixedterm contracts have a short duration and they terminate at no cost, they provide firms with a scope for wage adjustment: firms hire the new employees at lower wages than those who terminated their fixed-term contracts. The labor turnover on indefinite-term contracts is lower, particularly because most hiring occurs on fixed-term contracts. In addition, workers under indefinite-term contracts tend to be more protected-they have higher reservation wages and are more unionized. As a result, firms are unable to lower the wage of the native population covered by indefinite-term contracts.

While indefinite-term contracts exert a protective effect on wages, I find that an increase in the number of immigrants decreases the employment level of native workers under indefinite-term contracts. Firms use the exits of native workers under indefiniteterm contracts to replace them by immigrants. This substitution effect may be motivated by the fact that immigrants, being more inclined to accept lower wages and harder working conditions, are more profitable for firms than equally skilled natives. In contrast, I find that the population of native workers under fixed-term contracts does not experience any employment losses due to immigration but they reduce their number of hours worked.

The asymmetric impact of immigration on the wages and employment of natives by job contract shows the important role played by institutions. In particular, when the wages of natives are protected by their employment contract, their employment level adjusts in response to immigration.

\section{Endnotes}

${ }^{1}$ See Edo and Toubal (2015) for a complement study on the overall impact of immigration on French wages in the long run. See also the contribution of Ortega and Verdugo (2014) who study the occupational mobility among French natives in response to immigration over the period 1968-1999, as well as the study by Mitaritonna et al. (2014) on the impact of immigration on French firm's productivity.

${ }^{2}$ Edo (2015) uses the same time period and finds an inverse relationship between immigration and the wages of natives under fixed-term contracts. I go beyond this study in three important ways. First, I show that all my estimates are robust to an instrumental variable approach. Second, the present paper is devoted to provide the wage elasticity to immigration for the natives under fixed-term contracts. Third, I estimate not only the relationship between immigration and the wages of natives by job contract but also the relationship between immigration and native employment.

${ }^{3}$ The share of workers covered by indefinite-term contracts has slightly declined over time from $88.7 \%$ in 1990 to $86.9 \%$ in 2002 .

${ }^{4}$ This asymmetric result is, for instance, consistent with Grossman (1982): when the wages of natives are inflexible downward, firms substitute toward the relatively cheaper foreign labor.

${ }^{5}$ The instrumentation strategy should also attenuate any measurement error in the computation of immigrant shares at the skill-group level (Aydemir and Borjas 2011). 
${ }^{6}$ Our estimated wage elasticity of -0.9 is consistent with the wage elasticity of -1.2 found by Llull (2014) for the USA after addressing the endogeneity of immigration to wages.

${ }^{7}$ Notice that the French laws stipulate that a worker under a CDD has to be paid equally than a worker under a CDI for the same job. However, "this is obviously difficult to verify and enforce, and it appears not to be satisfied in practice" (Blanchard and Landier, 2002, p. 230).

${ }^{8}$ Employers can transform fixed-term contracts into an indefinite-term contract-the rest of short-term contracts being terminated at no cost. At the beginning of the 1990s, one third of all fixed-term contracts were converted to indefinite-term contracts at their termination (Abowd and Kramarz 1999). In fact, firms should have incentives to have permanent workers and, therefore, to transform fixed-term into indefinite-term contracts as long as it is costly for them to have vacant jobs and look for new employees.

${ }^{9}$ In France, over the 1990-2010 period, the studies by Edo (2015) and Edo and Toubal (2015) find that immigrants and natives of similar education and experience tend to be perfect substitutes in production.

${ }^{10}$ Edo (2015) uses the log mean wage rather than the mean log wage to estimate the impact of immigration on native wages.

${ }^{11}$ I use the 1982 census since this dataset contains consistent information with the employment surveys on nationality, birth country, education, age, and age of completion of schooling. I cannot use the 1975 French census since it does not provide enough information on the educational attainment of individuals.

${ }^{12}$ I use eight nationality groups to compute $\hat{M}_{j k t}$ : North-Africa, the rest of Africa, Spain-Portugal-Italy, Benelux-Germany-Ireland-UK-Denmark-Switzerland, the rest of Europe including Russia, Vietnam-Cambodge-Laos, America, and the rest of the world.

${ }^{13}$ The alternative equation is $\log \left(N_{j k t}^{\mathrm{FTC}} / N_{j k t}^{\mathrm{ITC}}\right)=\log \left(\phi_{j k t}^{\mathrm{FTC}} / \phi_{j k t}^{\mathrm{ITC}}\right)-\sigma_{N} \log \left(w_{j k t}^{\mathrm{FTC}} / w_{j k t}^{\mathrm{ITC}}\right)$. Brücker et al. (2014) also use this type of equation to estimate the elasticity of substitution between highly and low-skilled workers (as well as between natives and immigrants) for three European countries where wages are not assumed to be perfectly flexible.

${ }^{14}$ All first-stage estimates are available upon request.

${ }^{15}$ By 2002 , the immigrant share in the labor force is $8.1 \%$. Thus, the wage and employment responses to immigration can be obtained by multiplying $\beta$ by approximately 0.84 (see Borjas (2003) for details).

${ }^{16}$ Interestingly, this employment reaction is of similar magnitude to that reported in Borjas (2003) and Aydemir and Borjas (2007) when focusing on native wage reaction.

${ }^{17}$ To compute employment rates, I use the number of native workers under indefinite-term contracts or fixed-term contracts at the numerator. The regressor of interest is still the share of immigrants in the labor force.

${ }^{18}$ This magnitude is more reasonable than in Edo (2015) who finds a wage adjustment higher than $20 \%$. This difference in magnitude is mainly due to the definition of the dependent variable: while Edo (2015) uses the log mean wage, the present paper uses the mean log wage. Borjas (2014, chapter 5) also shows that this seemingly trivial definitional difference has a major impact on the estimates. 


\section{Appendix}

Table 4 Educational distribution of native workers by job contract (\%)

\begin{tabular}{|c|c|c|c|c|}
\hline & \multicolumn{4}{|c|}{ Education level } \\
\hline & High & Medium & Low & Total \\
\hline FTC & 19.1 & 49.2 & 31.7 & 100 \\
\hline ITC & 21.6 & 48.2 & 30.1 & 100 \\
\hline
\end{tabular}

Table 5 Experience distribution of native workers by job contract (\%)

\begin{tabular}{|c|c|c|c|c|}
\hline & \multicolumn{4}{|c|}{ Education level } \\
\hline & High & Medium & Low & Total \\
\hline FTC & 19.1 & 49.2 & 31.7 & 100 \\
\hline ITC & 21.6 & 48.2 & 30.1 & 100 \\
\hline
\end{tabular}

\section{Competing interests}

The IZA Journal of Migration is committed to the IZA Guiding Principles of Research Integrity. The author declares that he has observed these principles.

\section{Acknowledgements}

I am grateful to George Borjas, Frédéric Docquier, Sébastien Jean, Gianmarco Ottaviano, Gabriel Felbermayr, Hillel Rapoport, and Farid Toubal for the helpful comments. I would also like to thank the anonymous referee and the editor for the useful remarks.

Responsible editor: Amelie Constant

Received: 5 February 2016 Accepted: 12 February 2016

Published online: 13 April 2016

\section{References}

Abowd JM, Kramarz F. The analysis of labor markets using matched employer-employee data. Handbook of Labor Economics. 1999;3:2629-710.

Abowd JM, Kramarz F. The costs of hiring and separations. Labour Econ. 2003;10(5):499-530.

Altonji JG, Card D. The effects of immigration on the labor market outcomes of less-skilled natives. In: Immigration, trade, and the labor market. Chicago: University of Chicago Press; 1991. p. 201-34.

Amossé T. Pignoni MT. La transformation du paysage syndical depuis 1945. Données sociales. 2006:405:414.

Angrist JA, Kugler AD. Protective or counter-productive? Labor market institutions and the effect of immigration on EU natives. Econ J. 2003;113(488):F302-31.

Aydemir A, Borjas GJ. Cross-country variation in the impact of international migration: Canada, Mexico, and the United States. J Eur Econ Assoc. 2007;5(4):663-708.

Babecký J, Du Caju P, Kosma T, Lawless M, Messina J, Rõõm T. Downward nominal and real wage rigidity: survey evidence from European firms. Scand J Econ. 2010;112(4):884-910.

Babecký J, Du Caju P, Kosma T, Lawless M, Messina J, Rõõm T. How do European firms adjust their labour costs when nominal wages are rigid? Labour Econ. 2012;19(5):792-801.

Bentolila S, Dolado JJ, Franz W, Pissarides C. Labour flexibility and wages: lessons from Spain, Economic policy. 1994. p. 55-99.

Blanchard O, Landier A. The perverse effects of partial labour market reform: fixed-term contracts in France. Econ J. 2002;112(480):F214-44.

Borjas GJ. The labor demand curve is downward sloping: reexamining the impact of immigration on the labor market. Q J Econ. 2003;118(4):1335-74.

Borjas GJ. Immigration economics. Cambridge, Massachussetts: Harvard University Press; 2014.

Borjas GJ, Grogger J, Hanson GH. Immigration and the economic status of African-American men. Economica. 2010; 77(306):255-82.

Bratsberg B, Raaum O, Røed M, Schøne P. Immigration wage effects by origin. Scand J Econ. 2014;116(2):356-93.

Brücker H, Jahn EJ. Migration and wage-setting: reassessing the labor market effects of migration. Scand J Econ. 2011; 113(2):286-317.

Brücker H, Hauptmann A, Jahn EJ, Upward R. Migration and imperfect labor markets: theory and cross-country evidence from Denmark, Germany and the UK. Eur Econ Rev. 2014;66:205-25.

Card D. Immigrant inflows, native outflows, and the local labor market impacts of higher immigration. J Labor Econ. 2001;19(1):22-64.

Card D, Kramarz F, Lemieux T. Changes in the relative structure of wages and employment: a comparison of the United States, Canada, and France. The Canadian Journal of Economics. 1999;32(4):843-77.

Cohen D, Lefranc A, Saint-Paul G. French unemployment: a transatlantic perspective. Economic Policy. 1997;12(25):265-92.

Constant A, Krause A, Rinne U, Zimmermann K. Reservation wages of first and second generation migrants, CEPR Discussion Papers, 8208. 2011.

Cortes P. The effect of low-skilled immigration on US prices: evidence from CPI data. J Polit Econ. 2008;116(3):381-422. 
D'Amuri F, Peri G. Immigration, jobs, and employment protection: evidence from Europe before and during the great recession. J Eur Econ Assoc. 2014;12(2):432-64

D'Amuri F, Ottaviano GIP, Peri G. The labor market impact of immigration in western Germany in the 1990s. Eur Econ Rev. 2010;54(4):550-70.

Docquier F, Ozden Ç, Peri G. The labor market effects of immigration and emigration in OECD countries. Econ J. 2014; 124(579):1106-45.

Dustmann C, Fabbri F, Preston I. The impact of immigration on the British labour market. Econ J. 2005;115(507):F324-41.

Dustmann C, Frattini T, Preston IP. The effect of immigration along the distribution of wages. Rev Econ Stud. 2013;80(1): $145-73$.

Edo A. The impact of immigration on native wages and employment. The BE Journal of Economic Analysis \& Policy. 2015;15:3.

Edo A, Toubal F. Selective immigration policies and wages inequality. Rev Int Econ. 2015;23:160-87.

Elsner B. Emigration and wages: the EU enlargement experiment. J Int Econ. 2013;91(1):154-63.

Epstein GS, Gang IN. Migration and culture (Vol. 8). Bingley, United Kingdom: Emerald Group Publishing; 2010.

Felbermayr G, Geis W, Kohler W. Restrictive immigration policy in Germany: pains and gains foregone? Rev World Econ 2010;146(1):1-21.

Galor O, Stark O. The probability of return migration, migrants' work effort, and migrants' performance. J Dev Econ. 1991;35(2):399-405

Gerfin M, Kaiser B. The effects of immigration on wages: an application of the structural skill-cell approach. Swiss Journal of Economics and Statistics. 2010;146(IV):709-39.

Glitz A. The labor market impact of immigration: a quasi-experiment exploiting immigrant location rules in Germany. J Labor Econ. 2012;30(1):175-213.

Goux D, Maurin E, Pauchet M. Fixed-term contracts and the dynamics of labour demand. Eur Econ Rev. 2001;45(3):533-52. Gross DM, Schmitt N. The role of cultural clustering in attracting new immigrants. J Reg Sci. 2003:43(2):295-318.

Grossman JB. The substitutability of natives and immigrants in production. : : Review of Economics and Statistics; 1982. p. 596-603.

Katz LF, Murphy KM. Changes in relative wages, 1963-1987: supply and demand factors. Q J Econ. 1992;107(1):35-78. Kramarz F, Michaud ML. The shape of hiring and separation costs in France. Labour Econ. 2010;17(1):27-37.

Llull J. The effect of immigration on wages: exploiting exogenous variation at the national level, Barcelona GSE Working Paper Series Working Paper, 783. 2014.

Malchow-Møller N, Munch JR, Skaksen JR. Do immigrants affect firm-specific wages? Scand J Econ. 2012;114(4):1267-95.

Manacorda M, Manning A, Wadsworth J. The impact of immigration on the structure of wages: theory and evidence from Britain. J Eur Econ Assoc. 2012;10(1):120-51.

Messina J, Duarte CF, Izquierdo M, Caju P, Hansen NL. The incidence of nominal and real wage rigidity: an individualbased sectoral approach. J Eur Econ Assoc. 2010;8(2-3):487-96.

Mincer JA. Schooling, experience and earnings. New York: Columbia University Press; 1974.

Mitaritonna C, Orefice G, Peri G. Immigrants and firms' productivity: evidence from France. Working Paper CEPII. 2014. p. 09 Nickell S. Unemployment and labor market rigidities: Europe versus North America. J Econ Perspect. 1997;11(3):55-74. OECD. Perspectives des migrations internationales. Paris: OECD Publishing; 2007.

Ortega J, Rioux L. Durée des contrats et indemnisation du chômage. Presses de Sciences Po. 2002;53(6):1273-303.

Ortega J, Verdugo G. The impact of immigration on the French labor market: why so different? Labour Econ. 2014;29: $14-27$.

Ottaviano GIP, Peri G. Rethinking the effects of immigration on wages. J Eur Econ Assoc. 2012;10(1):152-97.

Peri G. The effect of immigration on productivity: evidence from US states. Review of Economics and Statistics. 2012; 94(1):348-58.

Stock JH, Wright JH, Yogo M. A survey of weak instruments and weak identification in generalized method of moments. J Bus Econ Stat. 2002;20:4.

\section{Submit your manuscript to a SpringerOpen ${ }^{\circ}$ journal and benefit from:}

- Convenient online submission

Rigorous peer review

- Immediate publication on acceptance

- Open access: articles freely available online

- High visibility within the field

Retaining the copyright to your article 